\title{
Problems of fishery development in primitive communities
}

\author{
By R. S. Rack*, Keelby, Grimsby, Lincs.
}

I have chosen for my contribution the development of primitive fishing communities and it may be well to examine the phrase at the outset. I confess that I am not altogether happy in the use of the word primitive: for whereas groups of simple peasant people may follow ways which are rudimentary by our standards, they are frequently logical and intelligent when examined against the appropriate background. I recall the weight of censure laid against a Central African tribe which had until recently been isolated in dense bush: 'They have not even developed a wheelbarrow'. It was true; but they had developed a sled which was far more practical as an alternative to the headed load when conditions permitted. I also remember vain attempts to introduce small sailing boats in place of paddled canoes. The theory was excellent but the practice impossible because the prevailing wind blew steadily in the wrong direction for days together. Life in an isolated community in which failure in hunting or fishing is equated with hunger leads eventually to traditional usage based on sound principles. Unfortunately undue emphasis on tradition leads to a conservatism which hampers further progress. I shall refer to this later.

Neither need the primitive community be of necessity uncivilized in the minimum sense. As Sir Mortimer Wheeler has said, 'Civilisation in a minimum sense of the term is the art of living in towns, with all that the condition implies in respect of social skills and discipline'. The purist may insist that the definition is scant in that it ignores all but the most meagre fruits of civilization; but it suits the context in which I hope to apply it. Our own society is surely a commercialized civilization in which disciplined employment, the wage structure, and a cash economy are distinguishing features. It is not so in many of the countries which are by commercial standards underdeveloped. A primitive community may have a pattern of social skills and discipline but of an entirely different order from our own. The differences present some of the most difficult problems in planned development; because of the importance I propose to discuss a few points in some detail.

When we refer to planned development we surely mean something more than organized manual employment without hope of advancement in ways which raise the stature and dignity of the individual. It should be, shall we say, something more than the distribution of the equivalent of tinned milk. It is, however, largely based on the introduction of a commercialized civilization which requires the patterns of disciplined employment which we know so well but which are quite foreign to a primitive community.

Working to a time table without supervision proves difficult to many who are emerging from a pattern of society in which time itself was of little consequence. A primitive community may have developed intricate patterns of behaviour, but they are entirely different from our own. Our modern communities must of necessity

*Died on 23 October, 1961. Formerly Fisheries Adviser to the Governor of the Windward Islands and to the Government of Northern Rhodesia. 
be punctual in their affairs, organizing work and leisure by the division of time. More primitive people prefer to subordinate time to circumstances. If, for example, a friend returns after long absence it is natural that more mundane duties be dropped in favour of feasting which may last several days or until supplies are exhausted, for African tribal hospitality is lavish without stint--and why not, when fish is to be had for the catching, meat in return for hunting, and beer brewed by the women readily available. There are of course many African or West Indian people who were themselves born in urban surroundings and have learned to accept the disciplines imposed. It is probable that the number will increase; but in the early days the pull between the cash economy with richer reward and the easy ways of the past is very real. Matters become still more difficult when members of a family or tribe are divided, for it then becomes necessary to travel long distances in order to reunite when occasions demand. Those who have employed African servants know only too well that events in a distant village may disrupt routine suddenly and without warning. A call has come, and the servants return home, nominally for a week but in reality for a period unspecified. I am convinced that these differences in habit and custom lead to misunderstanding and bitterness between many Europeans and African or West Indian peoples. The employer, planner, housewife, passenger, all become rightly incensed when the employee is absent without apparent cause, plans do not mature, the cook leaves with little warning, or the passenger waits until the schooner captain has fully welcomed his brother. Ingratitude, irresponsibility, laziness, and similar terms are used: what is not realized is that they are directed at those who, for the time being at least, have returned to other ways. Like Alice, they have slipped through the looking-glass.

What is much more important is that these difficulties have not always been taken into account when plans for fishery development have been drafted. It was once my duty to check proposed schemes for fishery development for which funds were sought. They usually followed a familiar pattern in which a carefully timed programme was to lead from early financial loss to eventual gains and a self-supporting economy. They assumed that the plans would be welcomed by fishermen who would co-operate by accepting working conditions involving full employment over regular hours. When such plans have been attempted the results have been frustration and a sense of failure. Planning must proceed with the co-operation of all concerned if it is to succeed.

Planned development should also take into account traditional habits and customs. If, for example, it has been usual for a boat owner to be accompanied by oarsmen or paddlers in exchange for a share of the catch the introduction of an engine may make little or no difference, for the cash economy of the engine is one thing but the tradition quite another. An enterprising boat owner may find losses accrue if an engine merely reduces labour by carrying oarsmen-fishermen as passengers not working their passage. It may be asked why the men do not catch more fish and so make the cost of running the engine worth while. Usually boats or canoes are too small to carry heavy pay-loads; and they must return quickly if the fish is to catch a market or remain fresh in the absence of ice. A more appropriate development might 
call for bigger boats carrying ice and capable of spending more time in fishing. Development of this order calls for technical training in advance and will be referred to later.

The tradition that fish is primarily for subsistence and only offered for sale when the requirements of the family and friends have been met is very strong, and when not carried to excess is only right and proper. When, however, there is plurality of marriage, and wives demand shares of the catch not only for subsistence but in order to obtain cash; when each fishing village may be crowded with claimants on hospitality; and when fish is used in payment for services, the margins available to the fishermen for the development of capital may be very little indeed. The pattern is a reflection of a society in which fishing was not equated with cash and fish could therefore be distributed freely or bartered. One reason why so few African fishermen become store keepers among the many Indians or Portuguese may be the demands made on their earnings so that they cannot accumulate preliminary capital. The problem is very real when development plans involving loans are considered.

It may be asked why development projects should be initiated at all. Why should not a primitive community be left to follow a traditional pattern of life until such time as it is changed by processes of evolution? The most usual answer is that the modern world has caught up the primitive communities in an expansion of its own amenities. These may be roads which link town and country or markets serving large urban populations which follow on industrial development. More spectacularly, as at Kariba, it may become necessary to settle a displaced community and train the people in fishing. With the innovation of the cash economy the older standards are replaced by our conventional divisions of wealth and poverty. The displays of the trading stores enhance the advantages of having money to spend. The younger men who are no longer satisfied with the older ideas tend to drift to the towns where they are all too easily caught up in vagrancy and unemployment. On the broader issues there is the desire of Government to introduce better standards of living, to develop the natural resources and produce more food, and to encourage means whereby communities may become more self supporting in bearing the burden of the social services. The alternative to development would be a form of apartheid which would be impracticable quite apart from the moral issues involved.

On the one hand, therefore, there is a general desire that projects for fishery development should be implemented by Government Agencies on the grounds that they contribute to the welfare and advancement of the indigenous people. On the other hand, there are very definite technical considerations which determine the nature and scope of the development: and to determine these it is usual to enlist the services of one or more consultants. Their terms of reference will be adapted to particular circumstances but the following conditions are in my view vital: first, a sufficient abundance of fish to meet present and future requirements; second, the availability of fishermen with adequate boats and gear; third, access to satisfactory markets. Unless these conditions are satisfied commercial developments become difficult or impossible. In arriving at their decisions the technical advisers will be required to make an assessment of the future in terms of supplies, the training of 
fishermen, and the expansion of markets. The services of a biologist, a specialist in fishing boats and gear, and an adviser on fish transport and marketing will be required together with assistance from resident officers with knowledge of local conditions. The time required for a preliminary survey may be a matter of months or years according to the amount of information already available. When the recommendations have been made Government should be in a position to allocate funds and recruit the necessary staff to implement development projects which may extend over several years. In the meantime resident officers will have initiated smaller projects designed to improve local conditions and prepare the way for a major development. An example may provide illustration.

The industrial development of Northern Rhodesia has made rapid advances during the postwar years, with the result that large urban populations of both Europeans and Africans have congregated in a series of mining towns known as the copperbelt. Within the same period the extension of systems of all-weather motor roads has linked these towns with a number of inland fisheries which were previously isolated. The volume of fish available was not known but was believed to be considerable. Large numbers of fishermen lived by the lakes or rivers on a subsistence level using primitive canoes and gear. Here were the three factors to which I have referred: the reasonable supplies of fish; the availability of fishermen and gear; the markets available to transport. The primary problem was therefore one of co-ordination so that supplies of fish, competency of fishermen, and market demands could be adjusted each to the other. I should add that the fisheries of Northern Rhodesia cover some ro 000 sq. miles of lakes, swamps, and rivers.

As a result of a survey made in the year I95 I a Department of Fisheries was added to Government Establishment and a small staff of Fishery Officers was recruited. It was their duty to train African assistants, to collect statistics of fish caught, to make biological investigations, to initiate improvements in fishing and in fish curing and handling. Some idea of the problems involved is indicated by the fact that, owing to difficulties in recruitment, an area much greater than the United Kingdom was covered by two Officers using Land Rovers under conditions which made travelling extremely difficult during the wet season. By $195^{2}$ it had been found that the most important fishery marketed an annual total of some 7600 tons of fish on landed weights. Of this some 4000 tons of fresh and 600 tons of dried fish had been sold to traders from the Belgian Congo which bordered the lake. Only 167 tons of fresh and 259 tons of dried fish had been sent to the Northern Rhodesian markets of the copperbelt. The primary problems were the diversion of fish supplies to the African population of the copperbelt and development of the use of fresh fish in place of dried. It was obvious that any overall expansion of the fishery was limited until better and bigger boats could replace the canoes used by the fishermen, and boat engines be introduced.

In an attempt to meet these problems Government provided funds for the erection of a small ice plant at the fishery and established a boat-building school as a form of rural welfare work with the object of teaching men to commence businesses as professional boat builders in the fishing villages. An office was opened on the 
copperbelt and advice was given to all who had interests in fish marketing. These included the management of the copper mines and the Town Management Boards (each of which built modern fish markets), fish traders seeking designs for fishcarrying vehicles and entrepreneurs looking for openings including refrigeration and ice making. The pattern of development was shared between the mines which were interested in the welfare of their employees, fish traders and others anxious to improve their business, municipalities which recognized the need to establish market amenities, and Government which exercised an overall interest, provided the background of technical assistance and financed public utilities such as an ice plant and a harbour together with a boat-building establishment. By 1958 the total volume of fish from this fishery had risen from 7600 tons landed weight to ro 000 tons, of which I 600 tons were sent to the copperbelt as fresh fish compared with 167 tons in $195^{2}$. Supplies to the Congo had fallen from 4000 tons of fresh fish in 1952 to 2500 tons. Supplies of dried fish to both the Congo and Northern Rhodesia had remained fairly constant, but had shown some tendency towards a steady increase. The casts to Government had been minimized by enlisting the active co-operation of other bodies. The traders of $195^{2}$ were principally European, but by $195^{8}$ the trade was largely in African hands; in this way a number of small businesses had been established so that the responsibilities of fish marketing were widely distributed and individual trading losses were not usually disastrous. In this way the African fish trader was able to learn his business. This could be regarded as the primary development of this fishery and further developments are now in hand. These include the provision of a school at which the subject of navigation, the handling of powered boats, the use of ice and elementary bookkeeping will be taught. A further survey has, I understand, been made and will report on the fish potential in the light of increased fishing, means whereby fishing methods and gear may be improved, and market trends. This I would describe as the second phase of development.

A rather different pattern of development followed the displacement of the Tonga people when their land was to be submerged to become Lake Kariba which supplies the Kariba Dam. This people had not fished on any scale although their home had been in the valley of the Zambesi: for, by tradition, the fishing had been the prerogative of the Barotsi who possessed the appropriate medicines. With the formation of the lake the position changed and the Tonga were willing to learn to fish. Starting from scratch a number of men were taken to a well-established fishery where they learned the rudiments of gill-net fishing. This was followed by intensive courses arranged by the Fishery Officer and the provision of gear for sale by Government Agencies at reasonable prices. Sites thought most convenient for markets were planned and supervised in order that the fishermen might learn something of the trade. Until conditions were disturbed by the spread of the notorious weed this rudimentary industry grew phenomenally. The men were quick to learn and ready markets were available. In the early stages the trade is in dried fish but supplies of ice will become available when plans are further advanced.

It will be seen that I make some distinction between the production of fresh iced fish and dried fish. My experience has been that fish does not really become a staple 
food unless it is offered in the fresh state. When dried it is used as a relish to a diet consisting principally of cereals, much as we use smoked fish. There is also considerable wastage in handling dried fish, partly owing to excessive de-hydration leading to crumbling, or poor drying which gives rise to moulds. Insect infestation is also prevalent. Further, it is not usual to salt fish or meats in Central Africa but to rely on drying by sun or fire.

Another development was followed on Lake Tanganyika to which Northern Rhodesia has access. For many years the local fishermen had caught a small sardinelike fish by means of torches suspended over the water on dark moonless nights. The fish are attracted to light much as a moth to a candle. The torches have now been replaced by incandescent lamps burning paraffin so that the fishing has improved considerably. A fish-grading and marketing scheme is in hand under the auspices of the Northern Rhodesia Industrial Development Board. The present political climate is too disturbed to permit prophecy, but I have no doubt that some progress may result eventually. Incidentally, it is interesting to note that the use of incandescent lamps in this way is well known to Mediterranean fishermen, some of whom emigrated to the Congolese shores of Lake Tanganyika, bringing their gear with them. The change from resinous torches to modern Tilley lamps was possibly due to several influences and so provides another example of fisheries development. The next move will probably be in the direction of submerged lights using old head lamps from cars.

Not all fishery development projects are successful. I recollect one in which the planner placed great stress on the provision of modern markets in place of the traditional stretch of beach or pavement. A market was designed, built, and approved by all concerned. When, however, it was announced that a small surcharge was necessary as market dues both sellers and buyers reverted to the beach or street. The fact was that the market was not strictly necessary at the time and rather than revert to legal compulsion I thought it better temporarily to abandon the market.

Perhaps the biggest blow to my own pride followed my attempt to form a Fishermen's and Traders Association whereby there might be greater amity between the two factions. I succeeded, formed the original committee and assisted in the election of the first President who then made his inaugural address. His opening words were fatal: 'Now that we have come together we can both unite in attacking this Government', and so on. I need hardly say that my support was hurriedly withdrawn.

There are many approaches to fisheries development and to our efforts to bridge the gap between the primitive people and the requirements of this modern world into which they are emerging. It was, I think, Aldous Huxley who pilloried many development schemes by observing that they solved one series of problems but created others of no less magnitude. That I believe to be true; and it is something to be avoided. As I have tried to show, fisheries development is only part of a general development involving higher standards of literacy and education. It also requires a high degree of confidence between all who are concerned. This is not easy in these days of political controversy and the fact that it has in some measure succeeded is in itself a compliment to both home and overseas governments. I think one should also 
pay tribute to the efforts of resident officers on whom so much responsibility rests. Their greatest compliment is surely when the newly independent states almost insist that they remain doing just as before. 